\title{
sciendo
}

\section{APPLICATION OF THE INSTITUTE OF INCOME REDISTRIBUTION IN THE FORM OF SOCIAL TRANSFERS IN EU COUNTRIES}

\author{
Irena Antošová ${ }^{1}$, Jana Stávková ${ }^{2}$
}

\begin{abstract}
The reduction in the number of households living at risk of poverty is a common objective of EU countries but the social policy of each member state is different. This paper provides an overview of components of social transfers and their share in total household incomes in EU countries. The aim of the paper is to assess the effectiveness of the social systems of each on the basis of the number of households at risk of poverty determined before and after the payment of social benefits. Four segments of EU countries were identified in cluster analysis according to their approach to social transfer settings using primary data from EU-SILC survey. The combination of high share of social benefits and low share of old age pensions proves to be better in the fight against poverty. The relationship between an economic performance and a functioning social policy system appears in EU countries.
\end{abstract}

\section{Keywords}

Social Transfer, Income Inequality, Poverty, Social Benefits, Old Age Pension

\section{Introduction}

Life in poverty is no longer just a phenomenon of developing countries but many economically advanced countries, including European Union countries, also have to deal with this problem. It is income poverty where insufficient income does not allow the household to achieve the required living standard (Stiglitz et al., 2009). Poverty reduction can be achieved by using social policy instruments by the state (Keeley, 2015). The different composition of social policy instruments brings different effects.

Two extreme positions of the relationship between social and economic policy can be encountered. One means the primacy of economic policy over social policy, which is seen as an insignificant part of economic policy. The second means a dominance of social policy given that economic policy is under the orientation set by social requirements and the task of economic policy is to create an economic environment for the fulfilment of social goals.

\footnotetext{
${ }^{1}$ Mendel University in Brno, Zemědělská 1, Brno, 613 00, Czech Republic. E-mail: irena.antosova@ @endelu.cz.

${ }^{2}$ Mendel University in Brno, Zemědělská 1, Brno, 613 00, Czech Republic. E-mail: jana.stavkova@ @endelu.cz.
} 
In most advanced countries, we see that each country seeks and implements a certain proportion of both policies between the two extremes mentioned above. We assume that social policy is part of economic policy in this study.

Social policy affects everyone's life. It contributes to the quality of life to a greater or lesser extent. Quality of life includes a subjective and also an objective component. The objective component of quality of life consists of measurable economic, social, health and environmental characteristics. In economic terms, our interest is to find out the income situation of households, income inequality, number of households living in material and financial deprivation and also indicators of poverty and social exclusion. The subjective component relates primarily to how an individual perceives his or her position in a society, how he or she can fulfil his needs, interests and expectations. If a person begins to suffer financially and materially, it is likely that social and psychological deprivation follows and it is often accompanied by social exclusion with all its consequences.

How to measure income inequality, how to get closer to the ideal condition of redistribution is the subject of many expert studies but also political decisions between two options, i.e. the application of the state's considerable responsibility for the citizen or the application of a liberal model based on individual responsibility of the individual. The prevailing model and derived welfare system of social security are different in each EU country.

Firstly, the poverty before social transfers is detected and then various types of social income are counted during the evaluating of the institute of social transfers and their influence on income poverty. It is therefore possible to see how social benefits can gradually eliminate poverty. Social welfare benefits include pension insurance, sickness insurance, maternity financial support, unemployment benefits, state social help etc. For the purposes of comparing the impact of social welfare systems on poverty reduction, it is necessary to make some unification because welfare systems are different in various countries. Fahey (2005) also points out that the income poverty we use to identify poverty and is measured according to limit line (poverty line) in the EU does not take into account income inequalities between states. The income inequalities between member states are so significant that the poverty line in richer countries could be the same value as aboveaverage income in poorer states. We follow this stream of literature and contribute to the issue of determining the structure of social transfers and the measurement of their efficiency in poverty reduction in member states in the European Union.

The aim of the submitted paper is to assess the fulfilment of the purpose of social transfers in individual EU countries with different social welfare systems in the form of monitoring their impact on reducing the number of households experiencing financial poverty. The two components of social transfers that will be used for monitoring the purpose of transfers are old age pensions and other social benefits. The aim of the paper is also to identify groups of countries with similar access to social policy and to contribute to this by revealing the relationship between the amount of social benefits and the performance of the economy. 


\section{Literature review}

The fight against poverty is the main common objective of social policies of many countries but the composition of their social policy instruments is different (Keeley, 2015). The focus is on the aging population in Europe. Whether it is effective to focus social policy mainly on old age pensions is a question (Kluge et al., 2019). Social transfers also affect health which is not at a sufficient level in households at risk of poverty. Álvarez-Gálvez and Jaime-Castillo (2018) show that social expenditures have a positive effect on health conditions.

Poverty rate and low-income households living at risk of poverty that are the target group of social policy can be determined objectively according to the income situation of their household. Chakravarty (2010) explains the income inequality as a difference in income among individuals and households in one population. Because of the unequal distribution of income, we can identify a section of the population that does not meet their needs because of lack of money. Households from this group live in material deprivation and at risk of poverty, sometimes even in social exclusion (Halleröd, Larsson, 2008). Perkins et al. (2012) add that income inequality reduces the efficiency of the whole economy. It is possible to fight against income inequality with using instruments such as taxes and transfers. The income inequality would be higher and also households living at risk of poverty would be more without these instruments of social policy (Keeley, 2015). Negative consequences, such as criminal activities, can appear in a society because of the income inequality (Kujala et al., 2019).

Nolan and Whelan (2010) point out that relying only on income during determination of poverty is questionable. Low incomes can be used to identify poverty but low incomes do not show what it is like to be poor, how people became poor and how they deal with it. However, analyses based on income allow an objective comparison of households.

At the beginning of the chain of life at risk of poverty there is financial and material suffering. Because of this fact the use of the institute of income redistribution in the form of social transfers is an effort in advanced countries. Social transfers are all cash flows from the state directly to individuals and households. Incomes are reduced by taxes, fees and other charges and on the contrary incomes are increased by transfer charges within the redistribution. The state uses its instruments to solving of income inequality among other things (Anderson, 2015).

The effort of efficiency of social transfers is common to all countries. According to Nicola (2013) efficiency means that all sources are maximally used within society and sources are used to the extent that brings the maximum level of satisfaction achieved with given inputs. Fialová (2004) states that efficiency can be defined as the relationship between the effect provided by the examined system and costs that are necessary to achieve it. Zerbe (2001) also explains efficiency in a similar way as the connection between the effect and costs and describes efficiency as the top criterion of rationality of expended costs. Mitchell (1991) describes the above mentioned effect using a model that shows the expected outcome in the form of reducing poverty in society at the end of the redistribution process. The contribution of Beckermann (1979), who has been dealing with the issue 
and many authors follow his views, is that he has developed a model that has allowed the derivation of three indicators to evaluate the effects of social transfers on poverty: the target of social transfers, the effect of overpayment that means overflow and reduction of the poverty gap. This conception is sometimes called the poverty gap or depth of poverty (Keeley, 2015).

Slaný (2003) characterizes the relationship between economic and social policy. Economic policy affects social policy mainly through the system of taxes, interest rates and exchange rates, income policy, distribution of resources from the state budget, system of tax relief, structural policy and living standards indirectly influenced by the inflation rate. On the other hand, social policy affects economic policy mainly by the quality and quantity of disposable labour, the conditions of employment of workers, the setting of conditions for wage and salary payments for social and health insurance purposes, the setting of conditions for granting social benefits, social security and social security benefits.

\section{Methodology}

The primary data source for this article is data from the EU-SILC selective survey (European Union - Statistics on Income and Living Conditions) of 2015. The extensive EU-SILC survey provides representative data not only showing the detailed income situation of households but also identifying the households. EU-SILC data present demographic characteristics, information about the social situation of the households, about housing and other. This survey is compulsory for each member state of the European Union according to the unified methodology. The EU-SILC survey is suitable source for international science research and policy advice (Krell, Frick, 2017). The methods of data collection are set centrally for member states and enable comparative analysis of European states what is used also in the study by Clair et al. (2016).

Table 1: Frequency of households in the EU-SILC survey in EU countries in 2015

\begin{tabular}{|l|c|l|c|l|c|}
\hline Country & $\begin{array}{c}\text { Number of } \\
\text { households } \\
\text { in EU-SILC }\end{array}$ & Country & $\begin{array}{c}\text { Number of } \\
\text { households } \\
\text { in EU-SILC }\end{array}$ & Country & $\begin{array}{c}\text { Number of } \\
\text { households } \\
\text { in EU-SILC }\end{array}$ \\
\hline Austria & 6045 & Germany & 12927 & Poland & 12183 \\
\hline Belgium & 6006 & Greece & 14096 & Portugal & 8740 \\
\hline Bulgaria & 4995 & Hungary & 7770 & Romania & 7415 \\
\hline Croatia & 6562 & Ireland & 5452 & Slovakia & 5637 \\
\hline Cyprus & 4357 & Italy & 17985 & Slovenia & 8685 \\
\hline Czechia & 7914 & Latvia & 6113 & Spain & 12367 \\
\hline Denmark & 6025 & Lithuania & 4849 & Sweden & 5859 \\
\hline Estonia & 5728 & Luxembourg & 3474 & United Kingdom & 9312 \\
\hline Finland & 10726 & Malta & 4233 & & \\
\hline France & 11390 & Netherlands & 9806 & & \\
\hline
\end{tabular}


The basic statistical unit in the EU-SILC survey are persons living in one household in the selected apartment. These persons share necessary household expenses together (Eurostat, 2017). The overview of the number of households involved in the EU-SILC survey in 2015 is provided in table 1 .

The fundamental variable in this study is household disposable income (DI) expressed monthly in Euros. Household disposable income is the total amount of money households have available for spending and saving after subtracting income taxes. Then disposable income of households before social transfers and disposable income before social benefits is used for the detection the amount of social transfers, old age pensions and other social benefits. Social transfers are calculated as an amount of social benefits and old age pensions. The calculation of the poverty is based on the income situation of households. Households live at risk of poverty if their equivalised disposable income is equal to the poverty line or their income is under the value of poverty line that is settled as $60 \%$ of median of equivalised disposable income of households (Eurostat ${ }^{1}, 2018$ ). The equivalised income calculation takes into account the number of members in the household and also their age. According to EU definitions, the head of the household has a coefficient of 1.0, children under the age of 13 have 0.3 and other children and other persons 0.5 . Firstly, it is necessary to calculate an equivalised household size $(E H S)$ with using previous coefficients:

$$
\text { EHS }=1+0,5 *\left(n_{\text {adult }}-1\right)+0,3 * n_{\text {child }}
$$

Based on the calculation of an equivalised household size (sometimes called a consumption unit size), the equivalised disposable income $(E D I)$ is determined according to the relationship: $E D I=D I / E H S$. The equalized disposable income includes all monetary income received from any source by each member of a household and takes into account the age profile of a household. Also Aisa et al. (2019) use this income indicator to determine poverty in Europe because of mentioned advantages.

The conversion coefficient is used as a weight for each case in the dataset EU-SILC. Then it is possible to generalize data from EU-SILC survey for each EU country with using a weighted arithmetic mean and that conversion rate. The conversion coefficient that is determined by Eurostat and that is part of the EU-SILC database allows the collected values from the sample file to generalize to the entire population of the country. The value of the conversion coefficient for a certain household in a sample file represents the amount of such households in the whole state, so the whole state means a base file.

Besides primary data EU-SILC, the secondary data was used to gain one variable in the correlation tests - GDP per inhabitant monthly in euro. Secondary data serves as an additional source for verification of the poverty rate before social transfers in the EU. The secondary data is freely available from the Eurostat database.

The Pearson correlation coefficient is computed for sample data for testing hypotheses about correlation between selected variables. The null hypothesis assumes no correlation between variables, no correlation between GDP per inhabitant and the share of social benefits in household incomes. The first hypothesis assumes positive correlation. A correlation reveals in the interval $(-1,1)$. If the correlation coefficient approaches value 1, the relation is stronger (Stangor, 2011). 
Cluster analysis is applied to categorize a data file (a set of objects, here households) into several groups (clusters). Objects within a cluster are as similar as possible and the object within a cluster with objects from other clusters is similar as little as possible. Similarity (distance) is evaluated in terms of several properties (factors) of objects, so this is a multicriteria analysis. The cluster procedure consists of more steps. The individual objects are gradually merged into small clusters and then small clusters are associated with larger clusters (Meloun, Militký, 2012).

Software IBM SPSS Statistics that is suitable for processing large data sets is used in this study for processing EU-SILC data. K-means algorithm for cluster analysis is also implemented in this mentioned software. K-means identifies quite homogeneous groups of cases based on selected characteristics. The algorithm requires the specification of the number of clusters at the beginning of the procedure. K-means creates clusters defined by their centroids that are points in space like clustered objects. Objects are assigned to clusters according to cluster's centroid to which the object's centroid is nearest. K-means algorithm progresses iteratively and recalculates the centroids at each step so that the clusters are centred until their position is constant. Distances between clusters are computed using Euclidean distance (IBM Knowledge Center, 2019).

\section{Results}

Income situation of households in each country in the EU is default and decisive figure for further analyses. The numbers of surveyed households are shown in table 1 . It is obvious from the Table 1 that we work with extensive representative survey realized by national statistical offices. Average income of households and other income characteristics including social transfers are calculated from mentioned representative survey data and then selective characteristics are recalculated to the whole population of a country using the conversion coefficient (conversion rate). The overview of the income situation in each EU country (Table 2) is not decisive for the purpose of this paper but it provides the view of income inequality.

Table 2: Average household disposable income (monthly in euro)

\begin{tabular}{|l|c|l|c|l|c|l|c|}
\hline Country & Income & Country & Income & Country & Income & Country & Income \\
\hline Luxembourg & 5363 & Finland & 3139 & Malta & 2163 & Poland & 976 \\
\hline Denmark & 3684 & Belgium & 3079 & Slovenia & 1815 & Latvia & 931 \\
\hline Ireland & 3602 & Netherlands & 3009 & Portugal & 1418 & Croatia & 918 \\
\hline Austria & 3381 & Germany & 2805 & Greece & 1245 & Lithuania & 834 \\
\hline United Kingdom & 3320 & Cyprus & 2497 & Estonia & 1200 & Hungary & 697 \\
\hline Sweden & 3262 & Italy & 2430 & Slovakia & 1119 & Bulgaria & 566 \\
\hline France & 3203 & Spain & 2174 & Czechia & 1119 & Romania & 398 \\
\hline
\end{tabular}


There are a number of several factors affecting the level of income which vary from country to country and therefore such an overview would have to be accompanied by a study of the effects of each factor. For these reasons, relative values are calculated in this article. The subject of our interest is to analyse the use of the institute of social transfers in individual EU countries. The share of social transfers in total income is shown in Figure 1. If we look at the graph (Figure 1) with the added number information, it is necessary to realize that it is a relative expression of each part of the whole income of households and information ability cannot be connected with the amount of incomes in absolute expression. Social transfers are also monitored separately (old age pensions and social benefits individually). Countries are lined up from the highest share of social transfers to the lowest share of social transfers in total household disposable incomes.

The graph (Figure 1) shows that the highest share of social transfers $(37-41 \%)$ is in households in Greece, Portugal and Sweden. On the other hand, households in Estonia, Malta and Latvia have the lowest share of social transfers (22-24\%). The share of old age pensions shows a totally different situation in individual countries that is not directly related to the size of the share of social transfers as a whole. The example is Greece, the country with the highest share of old age pensions $(37.11 \%)$ in relation to total income but the lowest share of social benefits (3.78\%). There are several factors that affect this situation, e.g. the share of old age retirees in the population. Greece is the third country with the highest proportion of pensioners in the EU (35.81\%), only behind Croatia (44.75\%) and $45.47 \%$ in Bulgaria (Eurostat ${ }^{2}$, 2018). Second factor is the duration of working life that is 35.4 year on average in the EU. One of the lowest duration of working life is in Greece, i.e. about 32.3 years (Eurostat ${ }^{3}, 2018$ ). The lowest share of old age pensions is in households in Ireland (15\%) but with the highest share of social benefits $(17 \%)$. Other economically advanced countries with sophisticated and stabilized social policies are approaching this value of share of socials benefits. The difference in the structure of social transfers that emerges from the overview (Figure 1) shows different social welfare systems and different social policy in individual countries in the EU when a level of wages or economic performance are not taken into account.

However, the relationship between the economic performance of a member state of the EU and the social policy system in a state exists. This relationship was confirmed by the correlation coefficient of previous defined variables. Secondary data for GDP per inhabitant (Eurostat, 2019) expressed in euro per month were used in the correlation analysis and the second variable of correlation analysis was the share of social benefits in household incomes calculated from EU-SILC microdata database. The Pearson correlation coefficient is the value 0.601 with 0.01 significance level.

The solution of income inequality and the use of social transfers for their purpose influence the income situation of households. A number of households living at risk of poverty in relative percentage expression obtained as a proportion of households at risk of poverty from all households in each country could be considered the basis for the purpose of social transfers. Households live on or below the poverty line if their equivalised disposable income does not achieve $60 \%$ of the median of household income in each EU country. This situation can also be subjectively expressed by satisfaction with living standards. 


\section{Figure 1: The share of social transfers in total household income}

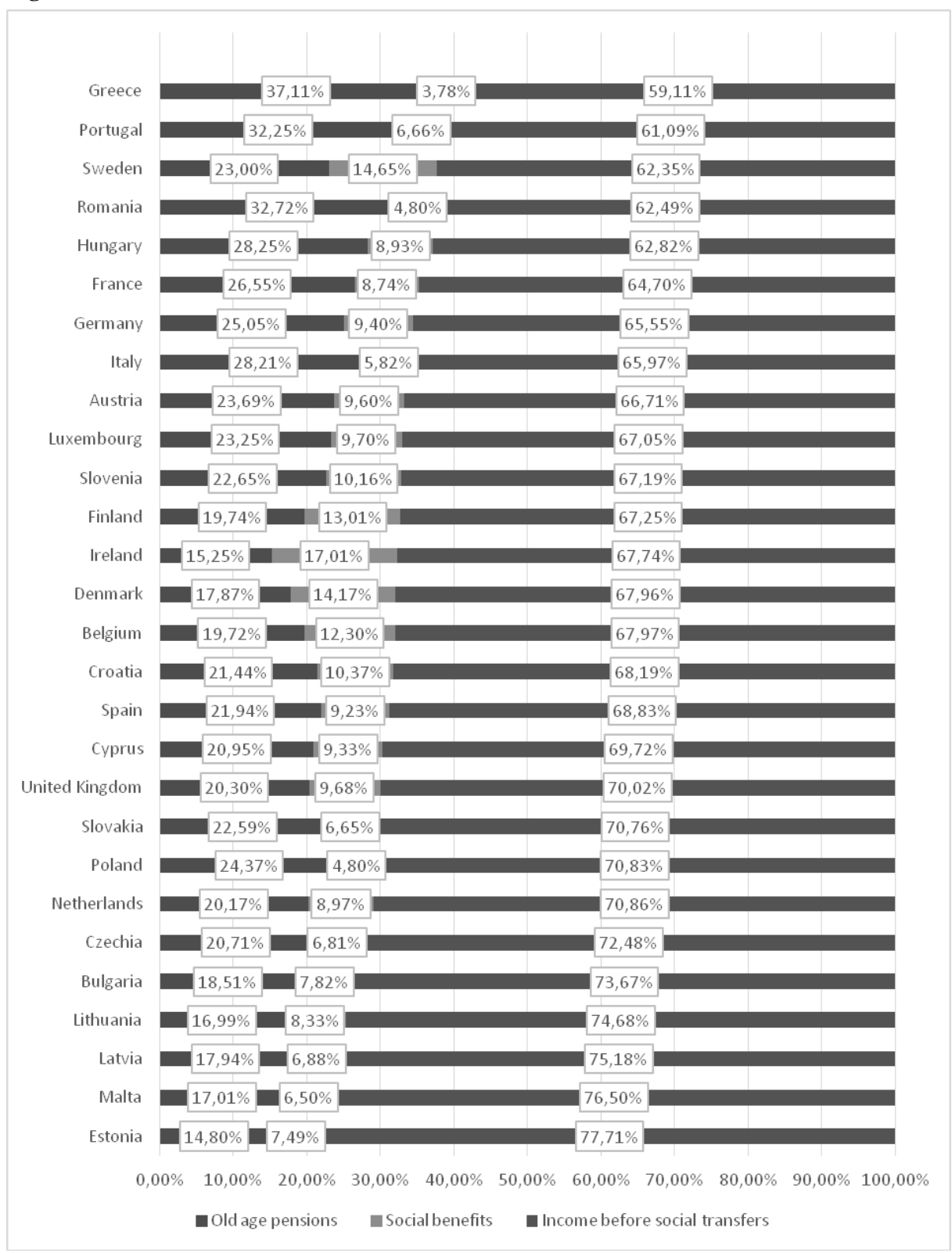


The figure 2 shows the difference between the number of households living at risk of poverty determined from household income including social benefits and the number of households living at risk of poverty without using social benefits. The different situation in the number of households at risk of poverty before providing social benefits and the number of households at risk of poverty after payment of social benefits is evident.

Figure 2: The difference between poverty and poverty before social benefits

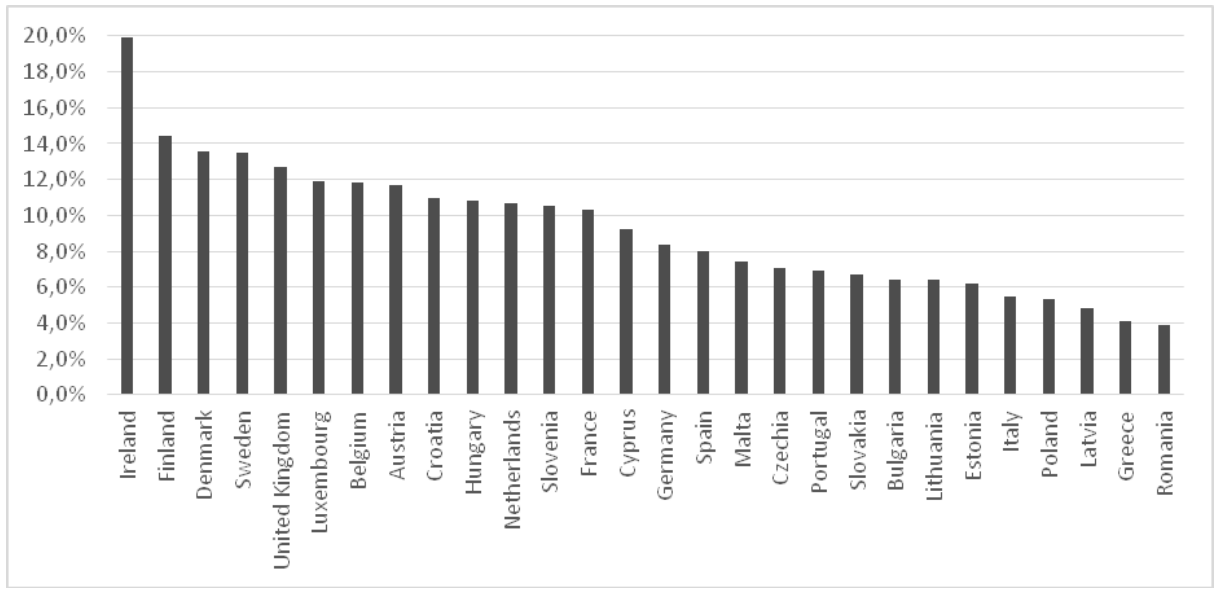

Reducing the poverty rate by less than $5 \%$ occurs in a group of countries with low economic performance, e.g. Romania, Greece, Latvia and Poland. The payment of social benefits brings a 10-15 percentage point reduction in the number of households at risk of poverty in economically developed countries (Finland, Denmark, Sweden) and with an implemented social welfare policy. The reduction of poverty in other EU countries with the payment of social benefits is about $6-12 \%$. Ireland has an extraordinary position where social transfers comprise especially of a higher proportion of social benefits than a proportion of old age pensions. It causes a 20 percent reduction in the number of households at risk of poverty after a payment of social transfers.

The cluster analysis was used for finding similarities of social policy, respectively of the effect of the system of social welfare transfers in the EU countries. The input variables in the cluster analysis were shares of a particular income component (income without social transfers, old age pensions and social benefits). The result of the segmentation is shown in Figure 3.

Created segments made up of four groups of countries:

* The first segment consists of countries with the lowest share of social transfers in total household income. Latvia, Lithuania, Malta, Bulgaria, Estonia and Czechia belong to this group. These are countries where the payment of social benefits brings about a 5-7\% poverty reduction. 
* The second segment consists of countries with an extraordinarily high share of old age pensions in social transfers and then also with a very low share of social benefits. Greece, Romania, Portugal, Hungary and Italy belong to this cluster.

* The third segment consists of the highest number of EU countries with a medium payment of social transfers that brings the reduction of poverty to about 8-12\%.

* The fourth segment consists of countries with a well developed social welfare system established over a long term period. Sweden, Finland, Belgium, Denmark and Ireland are classified into this group. The payment of social transfers brings the biggest effect in the fight against poverty. These countries also have high economic performance so again this involves the relationship between high economic performance of the country and a functioning social policy system that reduces the poverty rate effectively.

Figure 3: Cluster analysis

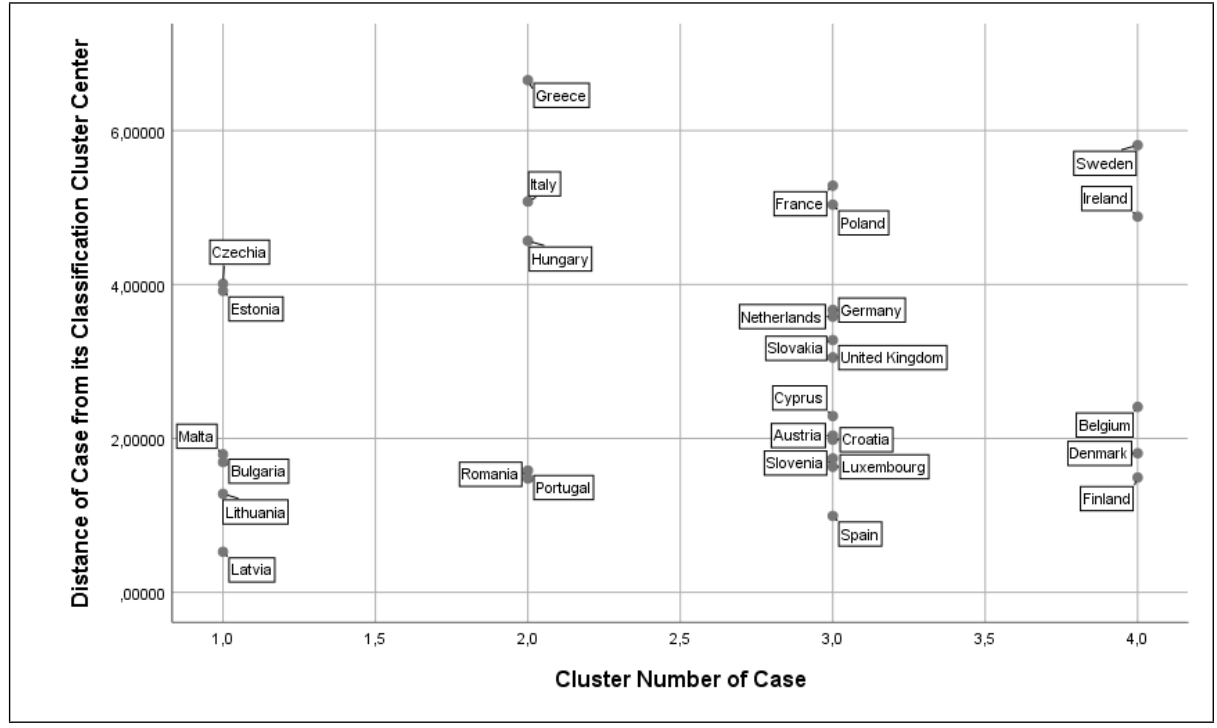

\section{Conclusion}

The analyses carried out in this study have confirmed that social policy systems and the structure of social welfare transfers are different and the fulfilment of their purpose is differently effective during social policy performance in member states in the European Union. There are countries with quite a high share of social transfers in household income but they mainly comprise of old age pensions without noticeable social benefits (Romania and Greece). The process of reducing the number of households living at risk of poverty is very slow in these countries. Then we have found the group of countries with a higher share of social benefits in household income. The focus not only on old age pensions but 
also on the substantial share of social benefits in household income is proving as effective because the highest reduction in the poverty rate after the payment of social transfers occurs in this group of countries where the share of social benefits in household income is higher. Sweden, Ireland, Finland, Belgium and Denmark belong to this group of countries with effective social policy, also focusing on the payment of social benefits. At the same time, it is appropriate to pay attention to countries that achieve the lowest poverty rates within EU countries and their social policy is effective (Netherlands, Czech Republic). The share of old-age pensions in household income is one of the lowest and the effect of social benefits is more positive also in these countries.

Most countries, especially the economically advanced, practise social policy at a level that provides good initial financial and material conditions to meet the living standard and quality of life of the population. The analyses carried out do not just serve as a statement about the differences between social systems but they are also an argument against the disproportionate effort to influence social systems in the EU countries in any way without taking into account differences between countries. The analyses match with the definition that the implemented social policy is at the same time 'policy' which means the choice of goals and means to achieve it. The cultural, political and economic development of each country has a significant impact on choosing these objectives and the means to achieve them and it also reflects the choice of combinations of social policy instruments that are differently effective in different countries. Common penetrations of the social systems in countries are not established yet. We can find a common objective but instruments and their use are a matter for each country.

\section{References}

Aisa, R., Larramona, G., Pueyo, F. (2019). Poverty in Europe by gender: The role of education and labour status. Economic Analysis and Policy, 63, 24-34.

Anderson, K. M. (2015). Social policy in the European Union. New York: Palgrave Macmillan.

Álvarez-Gálvez, J., Jaime-Castillo, A. M. (2018). The impact of social expenditure on health inequalities in Europe. Social Science \& Medicine, 200, 9-18.

Beckerman, W. (1979). Poverty and the impact of income maintenance programmes in four developed countries: case studies of Australia, Belgium, Norway, and Great Britain. Geneva: International Labour Office.

Chakravarty, S. R. (2010). Inequality, polarization and poverty. New York: Springer. Clair, A., Loopstra, R., Reeves, A., McKee, M., Dorling, D., Stuckler, D. (2016). The impact of housing payment problems on health status during economic recession: A comparative analysis of longitudinal EU SILC data of 27 European states, 2008-2010. SSM - Population Health, 2, 306-316.

Eurostat. (2017). EU statistics on income and living conditions (EU-SILC) methodology, available at: https://ec.europa.eu/eurostat/statistics-explained/index.php/EU_statistics_on _income_and_living_conditions_(EU-SILC)_methodology. 
Eurostat $^{1}$. (2018). Glossary: At-risk-of-poverty rate, available at: http://ec.europa.eu/eurostat/statistics-explained/index.php/Glossary:At-risk-of-poverty_rate.

Eurostat $^{2}$. (2018). Household characteristics by activity and employment status of the reference person, available at: http://appsso.eurostat.ec.europa.eu/nui/show.do?dataset=hbs _car_t311\&lang=en.

Eurostat $^{3}$. (2018). Duration of working life - annual data, available at: http://appsso.eurostat.ec.europa.eu/nui/show.do?dataset=lfsi_dwl_a\&lang=en.

Eurostat. (2019). Real GDP per capita, available at: https://ec.europa.eu/eurostat/tgm/refreshTableAction.do?tab=table \&plugin=1\&pcode $=$ sdg_08_10\&language $=$ en .

Fahey, T. (2005). The Case for an EU-wide Measure of poverty. European Sociological Review, 23(1), 35-47.

Fialová, H. (2004). Malý ekonomický výkladový slovník. Praha: A plus.

Halleröd, B., Larsson, D. (2008). Poverty, welfare problems and social exclusion. International Journal of Social Welfare, 17(1), 15-25.

IBM Knowledge Center. (2019). K-Means Cluster Analysis, available at: https://www.ibm. com/support/knowledgecenter/en/SSLVMB_24.0.0/spss/base/idh_quic.html.

Keeley, B. (2015). Income Inequality: The Gap between Rich and Poor. OECD Publishing. Paris.

Kluge, A. F., Goldstein, R. T., Vogt, C. (2019). Transfers in an aging European Union. The Journal of the Economics of Ageing, 13, 45-54.

Krell, K., Frick, J. R. (2017). Measuring the Consistency of Cross-sectional and Longitudinal Income Information in EU-SILC. The Review of Income and Wealth, 63(1), 30-52. Kujala, P., Kallio, J., Niemelä, M. (2019). Income Inequality, Poverty, and Fear of Crime in Europe. Cross-Cultural Research, 52(2), 163-185.

Meloun, M., Militký, J. (2012). Kompendium statistického zpracování dat. Praha: Karolinum.

Mitchell, D. (1991). Income Transfers in Ten Welfare States. Brookfield, USA: Avebury. Nicola, P. C. (2013). Efficiency and Equity in Welfare Economics. New York: Springer.

Nolan, B., Whelan, C. T. (2010). Using Non-Monetary Deprivation Indicators to Analyze Poverty and Social Exclusion: Lessons from Europe? Journal of Policy Analysis and Management. 29(2), 305-325.

Perkins, D. H., Radelet, S., Lindauer, D. L., Block, S. A. (2012). Economics of Development. New York and London: W. W. Norton.

Slaný, A. (2003). Makroekonomická analýza a hospodářská politika. Praha: C. H. Beck. Stangor, Ch. (2011). Research methods for the behavioral sciences. Belmont, CA: Wadsworth Cengage Learning.

Stiglitz, J. E., Sen, A., Fitoussi, J. (2009). Report by the Commission on the Measurement of Economic Performance and Social Progress, available at: http://ec.europa.eu/eurostat/ documents/118025/118123/Fitoussi+Commission+report.

Zerbe, R. O. (2001). Economic efficiency in law and economics. Northampton, MA: Edward Elgar. 